\title{
Use of plasma iodine assay for diagnosing thyroid disorders
}

P Allain, S Berre, N Krari, P Lainé-Cessac, A Le Bouil, N Barbot, V Rohmer, J C Bigorgne

\begin{abstract}
Aims-To examine the advantage of systematic plasma iodine assays in establishing the thyroid function of patients with thyroid disorders.

Methods-Iodine was determined by inductively coupled plasma mass spectrometry (ICPMS) in the plasma of 799 patients consulting for possible thyroid disorders, indicated by FT4 and TSH assays.

Results-Plasma iodine was below $40 \mu \mathrm{g} / 1$ in $57(7 \%)$ patients, most of whom had hypothyroidism; 40-80 $\mu \mathrm{g} / 1$ in 439 (55\%) patients, most of whom had normal thyroid hormone function; $80-250 \mu \mathrm{g} / 1$ in 240 $(30 \%)$ patients, most of whom had hyperthyroidism; and above $250 \mu \mathrm{g} / 1$ in $63(8 \%)$ patients, almost all of whom had iodine overload caused by iodinated drugs, particularly amiodarone, resulting in euthyroidism (24\%), hyperthyroidism (36\%), and hypothyroidism (16\%). Sixty five (7\%) had been treated with amiodarone and $27(3 \%)$ with other iodinated drugs. More than $10 \%$ of patients with thyroid disorders therefore had an iodine overload.

Conclusions-The determination of total plasma iodine using the simple, accurate ICPMS technique, should be carried out in patients consulting for thyroid disorders, particularly for the detection of an iodine overload.
\end{abstract}

\section{(F Clin Pathol 1993;46:453-455)}

The concentration of total plasma iodine in healthy subjects is between 40 and $80 \mu \mathrm{g} / 1,{ }^{1}$ but plasma iodine assays are not routinely applied and no systematic studies have been made in patients with thyroid disorders. Even in reports on excessive iodine intake from drugs, such as amiodarone, there are generally no data on plasma. The usual practice is to determine iodine in 24 hour urine samples, probably because this is easier than extracting the data from plasma.

\section{Methods}

Between June 1989 and December 1990, 799 patients consulting for thyroid disorders underwent plasma iodine assays in addition to the usual investigations such as free thyroxine (FT4) and thyrotropin hormone (TSH) measurements. The data were obtained at the first examination of the patients during the study period, even if many of them had already been examined and treated for thyroid disorders.

The use of inductively coupled plasma mass spectrometry (ICPMS) for plasma iodine assays has been described recently. Briefly, the sample preparation consisted of a 10-fold dilution of $200 \mu \mathrm{l}$ of plasma with $1800 \mu \mathrm{l}$ of a diluent containing $1 \%$ nitric acid and $25 \mu \mathrm{g} / 1$ of europium, used as an internal standard. The diluted plasmas were nebulised into the torch, and iodine and europium ions were measured at $\mathrm{m} / \mathrm{z}=127$ and 153 , respectively, with an ICPMS prototype from Nermag (Argenteuil, France). Mean (SD) plasma iodine concentrations in healthy subjects were 58 (12) $\mu \mathrm{g} / \mathrm{l}$, which agrees with other published data. ${ }^{1}$

FT4 and TSH were measured using commercial kits (Amerlite, Amersham) based on enhanced luminescence immunoassays.

\section{Results}

The results are summarised in table 1 . The patients were divided into four groups according to their plasma iodine concentrations $(<40 \mu \mathrm{g} / 1,40-80 \mu \mathrm{g} / 1,80-250 \mu \mathrm{g} / 1$ and $>250 \mu \mathrm{g} / \mathrm{l})$. Possible exposure to excessive iodine is indicated for patients with a plasma iodine above $80 \mu \mathrm{g} / \mathrm{l}$.

Among the 799 patients studied, 57 (7\%) had a plasma iodine concentration below 40 $\mu \mathrm{g} / 1,439(55 \%)$ between 40 and $80 \mu \mathrm{g} / 1,240$ (30\%) between 80 and $250 \mu \mathrm{g} / 1$, and $63(8 \%)$ above $250 \mu \mathrm{g} / \mathrm{l}$.

Group I, mean (SD) plasma iodine concentrations were $27(10) \mu \mathrm{g} / \mathrm{l}: 60 \%$ of the patients had hypothyroidism and $22 \%$ had normal FT4 and TSH activities. Notably, however, of the 13 patients with normal hormone function and iodine concentrations below $40 \mu \mathrm{g} / \mathrm{l}, 10$ had iodine concentrations between 32 and $40 \mu \mathrm{g} / 1$-nearly normal values.

In group II, mean (SD) plasma iodine concentrations were 60 (10) $\mu \mathrm{g} / 1$ : $63 \%$ had normal hormone function while the others had hyperthyroidism (6\%), hypothyroidism (3\%), or an unrelated condition with normal TSH and abnormal FT4 values, or vice versa (25\%).

In group III, mean (SD) plasma iodine concentrations were 128 (42) $\mu \mathrm{g} / \mathrm{l}: 60 \% \mathrm{had}$ hyperthyroidism and $21 \%$ had normal thyroid function.

In group IV, the plasma iodine concentrations were above $250 \mu \mathrm{g} / \mathrm{l}$, the mean value being 1342 (1 755) $\mu \mathrm{g} / 1$. Thyroid hormone function was normal in about $24 \%$, but $36 \%$ had hyperthyroidism and $16 \%$ hypothyroidism.

Table 1 shows that the patients with plasma iodine concentrations above $250 \mu \mathrm{g} / 1$ 
Table 1 Number, age, percentage and percentage of total number (\%T) of patients categorised by plasma iodine concentrations

\begin{tabular}{|c|c|c|c|c|c|c|}
\hline \multirow{2}{*}{\multicolumn{2}{|c|}{$\begin{array}{lc}\text { Patients: } & \begin{array}{c}\text { Number } \\
\text { Age (years) }\end{array} \\
\text { Ratio Men : Women ( } \mathrm{r} \text { ) }\end{array}$}} & $\begin{array}{l}\text { Group I } \\
\text { Iodine <40 } \\
\text { Mean (SD) } 27(10)\end{array}$ & $\begin{array}{l}\text { Group II } \\
40<=\text { iodine }<=80 \mu \mathrm{g} / \mathrm{l} \\
\text { Mean }(S D) 60(10)\end{array}$ & $\begin{array}{l}\text { Group III } \\
80<\text { iodine }<=250 \mu g / l \\
\text { Mean (SD) } 128(42)\end{array}$ & $\begin{array}{l}\text { Group IV } \\
\text { Iodine }>250 \mu g / l \\
\text { Mean (SD) } 1342 \text { (1755) }\end{array}$ & \multirow{2}{*}{$\begin{array}{l}\text { Total } \\
799 \quad(100 \% \mathrm{~T}) \\
52 \quad(19) \\
\mathrm{r}=0.205\end{array}$} \\
\hline & & $\begin{array}{l}57 \quad(7 \% \mathrm{~T}) \\
57 \quad(16) \\
\mathrm{r}=0 \cdot 208\end{array}$ & $\begin{array}{l}439(55 \% \mathrm{~T}) \\
51(18) \\
\mathrm{r}=0 \cdot 180\end{array}$ & $\begin{array}{l}240(30 \% \mathrm{~T}) \\
49(20) \\
\mathrm{r}=0.176\end{array}$ & $\begin{array}{l}63 \quad(8 \% \mathrm{~T}) \\
72(15) \\
\mathrm{r}=0.570\end{array}$ & \\
\hline $\begin{array}{l}0.15<=\text { TSH }<=4 \\
\text { TSH }<0.15 \\
\text { TSH }>4\end{array}$ & $\begin{aligned} & 12<= \text { FT } 4<=26 \\
& \text { FT4 }<12<12 \\
& \text { FT4 }>26 \\
& 12<= \text { FT4 }<=26 \\
& \text { FT4 }<12<12 \\
& \text { FT4 }>26 \\
& 12<= \text { FT4 }<=26 \\
& \text { FT4 } 4<12 \\
& \text { FT4 } 4>26\end{aligned}$ & $\begin{array}{rr}13^{\star} & (22 \%) \\
5 & (9 \%) \\
0 & \\
1 & \\
0 & \\
1 & \\
2 & \\
35 & (60 \%) \\
0 & \end{array}$ & $\begin{aligned} & 274(63 \%) \\
& 11(2 \%) \\
& 8(13 \%) \\
& 58(13 \%) \\
& 2(6 \%) \\
& 27(6 \%) \\
& 46(10 \%) \\
& 12(3 \%) \\
& 1\end{aligned}$ & $\begin{array}{cc}51 & (21 \%) \\
2 & \\
11 & (5 \%) \\
20 & (8 \%) \\
1 & \\
146 & (60 \%) \\
5 & \\
3 & \\
1 & \end{array}$ & $\begin{array}{r}15(24 \%) \\
0 \\
4(6 \%) \\
3(5 \%) \\
0( \\
23(36 \%) \\
6(10 \%) \\
10(16 \%) \\
2(3 \%)\end{array}$ & $\begin{array}{r}353 \\
18 \\
23 \\
82 \\
3 \\
197 \\
59 \\
60 \\
4\end{array}$ \\
\hline Exposure to excessi & $\begin{array}{l}\text { ive iodine: } \\
\text { Not found } \\
\text { Amiodarone } \\
\text { Others }\end{array}$ & & & $\begin{array}{r}206(86 \%) \\
18(7 \%) \\
16(7 \%)\end{array}$ & $\begin{array}{r}5(8 \%) \\
47(75 \%) \\
11(17 \%)\end{array}$ & $\begin{array}{l}65(8 \% \mathrm{~T}) \\
27(3 \% \mathrm{~T})\end{array}$ \\
\hline
\end{tabular}

TSH (mUl/l) and FT4 (pmol/1): ( ${ }^{1} 10$ of the 13 patients had plasma iodine concentrations between 32 and $\left.40 \mu \mathrm{g} / 1\right)$. The normal values for FT4 are $12-26 \mathrm{pmol} / 1$ and the normal values for TSH are $0 \cdot 15-4 \mathrm{mUV} /$.

Table 2 Patients $(n=66,8 \% T)$ with euthyroidism $(0 \cdot 15<T S H<4$ mUll and $12<F T 4<26$ pmolll) and iodine plasma concentrations above $80 \mu \mathrm{g} / \mathrm{l}$

\begin{tabular}{|c|c|c|c|c|}
\hline & \multirow{2}{*}{\multicolumn{2}{|c|}{$\begin{array}{l}\text { Group III } \\
80<\text { Iodine }<=250 \mu \mathrm{g} / \mathrm{l} \\
\text { Mean (SD) } 117 \text { (43) }\end{array}$}} & \multirow{2}{*}{\multicolumn{2}{|c|}{$\begin{array}{l}\text { Group IV } \\
\text { Iodine }>250 \mu g / l \\
\text { Mean (SD) } 1311 \text { (1846) }\end{array}$}} \\
\hline & & & & \\
\hline \multirow{3}{*}{$\begin{array}{l}\text { Patient numbers } \\
\text { Sex } \\
\text { Age (years) } \\
\text { Exposure to excessive iodine: } \\
\text { Not found } \\
\text { Amiodarone } \\
\text { Other drugs }\end{array}$} & \multicolumn{2}{|c|}{$\mathrm{n}=51(6 \% \mathrm{~T})$} & \multicolumn{2}{|c|}{$\mathrm{n}=15(2 \% \mathrm{~T})$} \\
\hline & $\begin{array}{l}12 \text { men } \\
52(19)\end{array}$ & $\begin{array}{l}39 \text { women } \\
42 \text { (18) }\end{array}$ & $\begin{array}{l}6 \text { men } \\
75(9)\end{array}$ & $\begin{array}{l}9 \text { women } \\
70(20)\end{array}$ \\
\hline & $\begin{array}{l}5 \\
7 \\
0\end{array}$ & $\begin{array}{r}32 \\
3 \\
4\end{array}$ & $\begin{array}{l}1 \\
4 \\
1\end{array}$ & $\begin{array}{l}1 \\
4 \\
4\end{array}$ \\
\hline
\end{tabular}

Table 3 Patients $(n=169,21 \% T$ ) with hyperthyroidism (TSH $<0.15 \mathrm{mUll}$ and FT4 $>26$ pmolll) and iodine plasma concentrations above $80 \mu \mathrm{g} / \mathrm{l}$

\begin{tabular}{|c|c|c|c|c|}
\hline & \multirow{2}{*}{\multicolumn{2}{|c|}{$\begin{array}{l}\text { Group III } \\
80<\text { Iodine <= } 250 \mu g / l \\
\text { Mean (SD) } 137(42)\end{array}$}} & \multicolumn{2}{|c|}{$\begin{array}{l}\text { Group IV } \\
\text { Iodine }>250 \mu \mathrm{g} / \mathrm{l}\end{array}$} \\
\hline & & & \multicolumn{2}{|c|}{ Mean (SD) $882(671)$} \\
\hline Patient numbers & \multicolumn{2}{|c|}{$\mathrm{n}=146(18 \% \mathrm{~T})$} & \multicolumn{2}{|c|}{$\mathrm{n}=23(3 \% \mathrm{~T})$} \\
\hline $\begin{array}{l}\text { Sex } \\
\text { Age (years) }\end{array}$ & $\begin{array}{l}21 \text { men } \\
51(21)\end{array}$ & $\begin{array}{l}125 \text { women } \\
48(20)\end{array}$ & $\begin{array}{l}5 \text { men } \\
74(11)\end{array}$ & $\begin{array}{l}18 \text { women } \\
68(18)\end{array}$ \\
\hline \multirow{2}{*}{\multicolumn{5}{|c|}{$\begin{array}{l}\text { Exposure to excessive iodine: } \\
\text { Not found }\end{array}$}} \\
\hline & 15 & 120 & 0 & $2(1<300 \mu \mathrm{g} / 1)$ \\
\hline Amiodarone & 5 & 1 & 5 & 14 \\
\hline Other drugs & 1 & 4 & 0 & 2 \\
\hline
\end{tabular}

tended to be older (72 (15) years) than the others (mean age about 50 years). The sex ratio in this group was 0.57 higher than the average of $0 \cdot 18$ for the other groups. In $86 \%$ of patients with plasma iodine concentrations between 80 and $250 \mu \mathrm{g} / \mathrm{l}$, no exposure to excessive iodine was established. The high concentration in these patients was probably directly linked to thyroid hormone activity. In contrast, $92 \%$ of patients with plasma iodine concentrations above $250 \mu \mathrm{g} / 1$ (58 out of 63) had been exposed to excessive iodine from iodinated drugs, particularly amiodarone. Overall, $11 \%$ of the 799 patients consulting for thyroid disorders had iodine excess due to drug treatment.

Table 2 shows that 66 patiente with normal thyroid hormone function had abnormally high plasma iodine concentrations. In the group with plasma iodine concentrations between 80 and $250 \mu \mathrm{g} / 1(\mathrm{n}=51)$, more often than not, exposure to iodinated drugs was not recorded; in the group with values above $250 \mu \mathrm{g} / \mathrm{l} \quad(\mathrm{n}=15)$, iodinated drug use was found in 13 patients.

Table 3 shows that 169 patients $(21 \%$ of the total) had hyperthyroidism and plasma iodine concentrations above $80 \mu \mathrm{g} / 1$. Most of the patients with plasma iodine concentrations between 80 and $250 \mu \mathrm{g} / 1$ were women with no established exposure to excessive iodine, the high iodine concentrations probably resulting from Graves' disease. In patients with plasma iodine values above $250 \mu \mathrm{g} / \mathrm{l}$, excessive exposure to iodinated drugs, particularly amiodarone, was almost always found. Two women for whom no excessive iodine intake was established had plasma iodine concentrations of 270 and $290 \mu \mathrm{g} / \mathrm{l}$-values compatible with Graves' disease.

Table 4 shows that 13 patients (less than $2 \%$ of the total) had hypothyroidism and plasma iodine concentrations above $80 \mu \mathrm{g} / 1$. Twelve had received iodinated drugs, usually amiodarone.

\section{Discussion}

We have taken into account three biochemical variables of thyroid disorders: plasma iodine, FT4, and TSH values. The main advantages of ICPMS in plasma iodine assays are that it is a direct method, requiring only a simple dilution, and that it permits simultane- 
Table 4 Patients $(n=13,<2 \% T)$ with hypothyroidism (TSH $>4$ mUll and FT4 < 12 pmolll) and iodine plasma concentrations above $80 \mu \mathrm{mg} / \mathrm{l}$

\begin{tabular}{|c|c|c|c|c|}
\hline & \multirow{2}{*}{\multicolumn{2}{|c|}{$\begin{array}{l}\text { Group III } \\
80<\text { Iodine }<250 \mu g / l \\
\text { (Mean (SD) } 144(47)\end{array}$}} & \multirow{2}{*}{\multicolumn{2}{|c|}{$\begin{array}{l}\text { Group IV } \\
\text { Iodine }>250 \mu g / l \\
\text { Mean (SD) } 1638(1161)\end{array}$}} \\
\hline & & & & \\
\hline $\begin{array}{l}\text { Patient numbers } \\
\text { Sex } \\
\text { Age (years) }\end{array}$ & $\begin{array}{l}\mathrm{n}=3(<0.4 \% \mathrm{~T}) \\
0 \text { men }\end{array}$ & $\begin{array}{l}3 \text { women } \\
40 \text { (13) }\end{array}$ & $\begin{array}{l}\mathrm{n}=10(< \\
3 \text { men } \\
75(5)\end{array}$ & $\begin{array}{l}7 \text { women } \\
74 \text { (17) }\end{array}$ \\
\hline $\begin{array}{l}\text { Exposure to excessive iodine: } \\
\text { Not found } \\
\text { Amiodarone } \\
\text { Other drugs }\end{array}$ & $\begin{array}{l}0 \\
0 \\
0\end{array}$ & $\begin{array}{l}1 \\
0 \\
2\end{array}$ & $\begin{array}{l}0 \\
2 \\
1\end{array}$ & $\begin{array}{l}0 \\
6 \\
1\end{array}$ \\
\hline
\end{tabular}

ous determination of iodine and bromine. The technique determines total iodine-that is, iodide and iodine incorporated into thyroid hormones and into iodinated drugs. A thyroxine concentration of $80 \mu \mathrm{g} / \mathrm{l}$, a normal value, corresponds to $52 \mu \mathrm{g} / 1$ of iodine.

The plasma iodine concentrations used as criteria for categorising the patients into four groups are only tentative. They are not entirely satisfactory, particularly when the results are close to normal values. Thus $22 \%$ of the patients with plasma iodine concentrations below $40 \mu \mathrm{g} / 1$ had normal thyroid hormone function, but in fact most of them had concentrations between 32 and $40 \mu \mathrm{g} / \mathrm{l}$-that is, close to normal. Plasma iodine concentrations above $80 \mu \mathrm{g} / 1$ and even above $250 \mu \mathrm{g} / 1$ are compatible with hormonal euthyroidism, but values between 80 and $250 \mu \mathrm{g} / 1$ are strongly suggestive of hyperthyroidism, and values above $250 \mu \mathrm{g} / 1$ are almost always found in patients treated with iodinated drugs.

When plasma iodine concentrations are higher than $250 \mu \mathrm{g} / \mathrm{l}$, there is no simple relation between iodine concentration and hormone function. Indeed, the mean plasma iodine concentration in patients with hyperthyroidism was $882(671) \mu \mathrm{g} / \mathrm{l}$, whereas it was 1311 (1864) $\mathrm{mg} / \mathrm{l}$ and 1636 (1161) mg/l, respectively, in patients with hormonal euthyroidism and hypothyroidism. Thus very high plasma iodine concentrations do not always attend hyperthyroidism.

The drug most often implicated in iodine overload is amiodarone: $8 \%$ of the 799 patients were taking or had taken this drug. It has been reported that during treatment the amiodarone concentration may reach $3 \mathrm{mg} / 1,{ }^{2}$ which corresponds to $1125 \mu \mathrm{g} / 1$ of iodine because amiodarone contains $37 \%$ iodine. Moreover, iodide is progressively released from the amiodarone molecule stored in tissues. $^{3}$ The plasma half-life of amiodarone itself is about 25 days. ${ }^{45}$

Soon after it was introduced into Europe some 20 years ago, it was recognised that amiodarone may induce hyperthyroidism and sometimes hypothyroidism. ${ }^{6-9}$ Several authors ${ }^{1014}$ have recently shown that the prevalence of thyroid disorders in patients treated with amiodarone may be as high as $20 \%$.

Iodine overload from amiodarone is easily suspected and found in patients, often men, treated with this drug for cardiac disorders, but iodine overload from other drugs is difficult to assess because of the large number of iodinated drugs in use. Moreover, the presence of iodine is not always indicated on the packaging. In some cases amiodarone may not be suspected because thyroid disorders could develop even after treatment has been stopped.

In our study $11 \%$ of the patients consulting for thyroid disorders had been exposed to excessive iodine from drugs. Thus systematic determination of plasma iodine is clearly important. Indeed, whenever a plasma iodine concentration is above $250 \mu \mathrm{g} / \mathrm{l}$, the probability that an iodinated drug has been used is very high.

In conclusion, when plasma iodine concentrations are below $40 \mu \mathrm{g} / 1$, hypothyroidism is highly likely, when they are between 80 and $250 \mu \mathrm{g} / \mathrm{l}$, hyperthyroidism, particularly Graves' disease, is probable, and when they are above $250 \mu \mathrm{g} / 1$ iodine overload is almost certainly indicated. We are greatly indebted to the Laboratoire de Biophysique,
CHU, Angers, (Professor P Jallet) for the FT4 and TSH assays, and to the Fondation Langlois for a grant.

1 Allain P, Mauras Y, Dougé C, Jaunault L, Delaporte T, Beaugrand $C$. Determination of iodine and bromine in plasma and urine by inductively coupled plasma mass plasma and urine by inductively coupled

2 Borowski GD, Garofano CD, Rose LI, et al. Effect of long-term amiodarone therapy on thyroid hormone levels and thyroid function. $A m \Im \mathcal{Y} M e d 1985 ; 78: 443-50$.

3 Kennedy RL, Griffiths H, Gray TA. Amiodarone and the thyroid. Clin Chem 1989;35:1882-7.

4 Veronese ME, McLean S, Hendriks R. Plasma protein binding of amiodarone in a patient population: measurement by erythrocyte partitioning and a novel glasssurement by erythrocyte partitioning and a novel glass-

5 Somani P. Basic and clinical pharmacology of amiodarone: relationship of antiarythmic effects, dose and darone: relationship of antiarythmic effects, dose and drug concentrations to intracellu

6 Barrillon A, Himbert J. Amiodarone et thyroide. Presse Med 1971;79:1498.

7 Massin JP, Thomopoulos P, Karam J, Savoie JC. Le risque thyroidien d'un nouveau coronarodilateur iodé: l'Amiodarone (Cordarone). Ann Endocrinol 1971;32: 438-49.

8 Guinet P, Pousset G, Briere J, Grand Smith Bianchi G. Contribution à l'étude du myxoedème à l'iode. A propos d'un cas à l'amiodarone. Rev Française Endocrinol Clin 1972;13:229-42.

9 Daubèze J, Roger $\mathrm{P}$, Conri $\mathrm{C}$, et al. Hyperthyroïdie chez des maladies traités par l'amiodarone. Bordeaux Médical des maladies traites

10 Vrobel TR, Miller PE, Mostow ND, Rakita L. A general overview of amiodarone toxicity: its prevention, detecoverview of amiodarone toxicity: its prevention, detection, and

11 Nademanee K, Piwonka RW, Singh BN, Hershman JM. Amiodarone and thyroid function. Prog Cardiovasc Dis 1989;XXXI:427-37.

12 Simonin R. Dysthyroïdies par amiodarone. Fréquence et diagnostic. Arch Mal Coeur 1989;82:1747-50.

13 Hoogman RPLM, Heide DVD. Amiodarone and thyroid function. Netherlands $\mathcal{F}$ Med 1990;36:209-16.

14 Figge HL, Figge J. The effects of amiodarone on thyroid hormone function: a review of the physiology and clinical manifestations. $f$ Clin Pharmacol 1990;30. 588-95. 